ISSN: 2224-0616

Int. J . Agril. Res. Innov. \& Tech. 3 (1): 20-25, J une, 2013 Available online at http:// www.ijarit.webs.com

\title{
CHEMICAL FRACTIONATION OF CU AND ZN AND THEIR IMPACTS ON MICROBIAL PROPERTIES IN SLIGHTLY CONTAMINATED SOILS
}

\author{
Liu Aiju'*, Wang Honghai' ${ }^{2}$, Gao Peiling', Xu Hong-zhi ${ }^{3}$
}

Received 12 March 2013, Revised 4 June 2013, Accepted 20 June 2013, Published online 30 June 2013

\begin{abstract}
Chemical fractionation of $\mathrm{Cu}$ and $\mathrm{Zn}$ in bulk soil and its effects on soil microbial properties were determined in $\mathrm{Cu}$ and $\mathrm{Zn}$ contaminated soils $\left(\mathrm{Cu}: 35.57 \sim 46.37 \mathrm{mg}^{-1} \mathrm{~kg}^{-1}, \mathrm{Zn}\right.$ : 74.33 127.20 mg. $\mathrm{kg}^{-1}$ ) sampled from an agricultural field in outskirts of Zibo, China during the month of September, 2011. A sequential extraction technique (SET) was used for metals chemical fractionation analysis in soils and a correlation analysis was applied to determinate the effects of metal on soil microbial properties. Chemical speciation showed that $\mathrm{Cu}$ and $\mathrm{Zn}$ were mostly present in the residual fraction and their concentrations in the most labile fraction (acid soluble fraction) were the lowest in the investigated soils. However, the correlation analysis indicated that the labile forms of $\mathrm{Cu} / \mathrm{Zn}$, such as its acid soluble, reducible or oxidizable fractions, were usually significantly negatively correlated with the tested microbial activities at 0.05 or 0.01 probability levels. These results indicate that the metal labile fractions could exert an inhibitory effect on the soil microbial parameters even in the minor contaminated soils.
\end{abstract}

Keywords: Chemical Fractionation, Heavy Metals, Microbial Biomass, Soil Enzymes

${ }^{1}$ School of Recourse and Environmental Engineering, Shandong University of Technology, 12 Zhangzhou Road, Zibo 255049, China

${ }^{2}$ Zibo entry-exit inspection and quarantine bureau, 63 Liuquan Road, Zibo 255033, China

${ }^{3}$ Analysis \& Testing Center, Shandong University of Technology, 12 Zhangzhou Road, Zibo 255049, China

*Corresponding author's email: liuajnju@yahoo.com.cn (Liu Aiju)

\section{Introduction}

Soil microbial biomass and enzyme activities are considered to be good bio-indicators reflecting natural and anthropogenic disturbances, and evaluating soil enzyme activities is one of the cheapest and easiest techniques that can be used to evaluate soil pollution (Hinojosa et al., 2004; Khan et al., 2007). A considerable body of information has been accumulated in the last century on the inhibition of heavy metals on soil microbial activities and the factors that affect this inhibition (Karaca et al., 2010). Nevertheless, an enormous disparity of results is evident from the studies, in particular such as the concentration to which metal is toxic (Ge et al., 2000; Li et al., 2001). These discrepancies are due to factors, which modify the toxicity of the metals and to the differences in sensitivity of soil enzymes (Giller et al., 2009; Karaca et al., 2010).

Beside the environmental factors, microbial toxicity of heavy metals had been attributed to the two factors: metal concentration and bioavailability. The available forms of a metal are significant when attempting to understand metal toxicity, and its available forms are related to its chemical forms in the soil (Wang et al., 2007a, b). Several workers studied the correlation between metal forms and microbial activities in long-term contaminated soils (Wang et al., 2007a, b; Bhattacharyya et al., 2008), but not much information is available on the relationship of different metal fractions and soil microbial activities in slightly contaminated soils with trace metals.

Present work aimed to study chemical fractionation of $\mathrm{Cu}$ and $\mathrm{Zn}$ in bulk soil and its effects on soil microbial biomass and enzymes activities in minor $\mathrm{Cu}$ and $\mathrm{Zn}$ contaminated soils.

\section{Materials and Methods}

\section{Study area and samples collection}

The study sites are situated at the agricultural fields grown with wheat and corn in the outskirts of Zibo, China $\left(36^{\circ} 48^{\prime} \mathrm{N}, 118^{\circ} \mathrm{O} 3^{\prime} \mathrm{E}\right)$. Four sites were selected, of which the site 1,2 and 4 lie in district of Zibo city, the site 3 is near to industrial area.

Three surface soil samples from each of the 4 selected study sites were collected during the month of September, 2011. Altogether 12 soil samples were brought to the laboratory in the sealed polythene bags. The soils were passed through a $2 \mathrm{~mm}$ sieve and dispersed well. A 
portion of the soil samples was air-dried for chemical analysis. The others were store at $4^{\circ} \mathrm{C}$ for microbial analysis, which was completed within two weeks.

\section{Physico-chemical analysis of soils}

The $\mathrm{pH}$ was determined in soil: water @ 1:2.5 suspensions. Organic carbon (OC) and total metal contents were determined by the method of $\mathrm{Lu}$ (1999). Soil texture was determined with a laser particle size analyzer (Model: Rise-2028, China).

\section{Fractionations of metals}

Chemical fractionation of trace metal $\mathrm{Cu}$ and $\mathrm{Zn}$ in soil was carried out following a sequential extraction technique (Quevauviller et al., 1997). To explain the method briefly, $1.0 \mathrm{~g}$ of soil samples (in dry weight) were sequentially extracted with $0.11 \mathrm{M} \mathrm{CH}_{3} \mathrm{COOH}$ (16 h shaking, $120 \mathrm{rpm}$ ) for acid soluble fraction, with $0.1 \mathrm{M}$ $\mathrm{NH}_{3} \cdot \mathrm{HCl}(\mathrm{pH}=1.5,16 \mathrm{~h}$ shaking, $120 \mathrm{rpm}$ ) for reducible fraction, with $8.8 \mathrm{M} \mathrm{H}_{2} \mathrm{O}_{2}(\mathrm{pH}=2)$ at room temperature ( $1 \mathrm{~h}$, shaking, $120 \mathrm{rpm})$ and 85 $\square(1 \mathrm{~h}$, shaking, $120 \mathrm{rpm})$, and then added $1 \mathrm{M}$ $\mathrm{NH}_{4} \mathrm{COOH}(\mathrm{pH}=2,16 \mathrm{~h}$ shaking, $120 \mathrm{rpm})$ for oxidizable fraction, and finally with concentrated $\mathrm{HNO}_{3}$ at $105^{\circ} \mathrm{C}$ for residual faction. As concentrations in the extracts were measured by ICP-MS (7500ce, Agilent, USA) and the results were expressed on a moisture-free basis.

\section{Microbiological analysis}

Microbial biomass carbon (MBC) content was determined by the fumigation extraction method
(Gregorich et al., 1990) using $\mathrm{K}_{\mathrm{EC}}\left(\mathrm{K}_{\mathrm{EC}}\right.$ is the calibration factor) factor of 0.38 (Joergensen, 1995). Urease, Dehydrogenase and arylsulphatase activities of soils were estimated following the methods suggested by Tabatabai and Bremner (1970, 1972); Trevors (1984); García et al. (1993) respectively. These measurements were performed using the field moist soils. However, the parameters were expressed on a moisture-free basis.

\section{Statistical analysis}

The significance of differences among the parameters was tested by two-way analysis of variance (ANOVA) followed by Tukey's test. Pearson correlation analysis and partial correlation analysis were performed to investigate the forms of metals suppressing the soil microbial activities in the soil. All statistical analyses were carried out with the program SPPS 17.0 for Windows.

\section{Results and Discussion}

\section{Physico-chemical properties of soil}

Table 1 shows the properties of the sampled soils. The soils were slightly alkaline in nature as the $\mathrm{pH}$ values ranged from 7.39 to 7.54 . Organic carbon contents of the soil samples were ranged from $7.76 \%$ to $8.70 \%$, which are somewhat lower than or comparable with other agriculture soils in China (Meng et al., 1996; Dai et al., 2009) and the clay contents were ranged from $45.53 \%$ to $48.87 \%$. No differences were found between the investigated sites on the tested soil properties.

Table 1. Soil characteristics and heavy metals contents at each sampling sites

\begin{tabular}{llllll}
\hline Sample sites & $\mathrm{pH}$ & $\mathrm{OC}(\mathrm{g} / \mathrm{kg})$ & Clay $(\%)$ & $\mathrm{Cu}\left(\mathrm{mg}^{\circ} \mathrm{kg}^{-1}\right)$ & $\left.\mathrm{Zn}^{-} \mathrm{mg}^{-\mathrm{kg}^{-1}}\right)$ \\
\hline 1 & $7.52 \pm 0.06 \mathrm{a}^{*}$ & $8.30 \pm 0.11 \mathrm{a}$ & $45.53 \pm 2.30 \mathrm{a}$ & $41.23 \pm 1.50 \mathrm{a}$ & $83.33 \pm 1.53 \mathrm{a}$ \\
2 & $7.54 \pm 0.09 \mathrm{a}$ & $8.02 \pm 0.14 \mathrm{a}$ & $48.87 \pm 1.89 \mathrm{a}$ & $35.17 \pm 2.76 \mathrm{~b}$ & $121.01 \pm 5.31 \mathrm{~b}$ \\
3 & $7.44 \pm 0.01 \mathrm{a}$ & $8.50 \pm 0.10 \mathrm{a}$ & $57.73 \pm 3.02 \mathrm{a}$ & $46.37 \pm 0.95 \mathrm{C}$ & $127.20 \pm 4.58 \mathrm{~b}$ \\
4 & $7.39 \pm 0.03 \mathrm{a}$ & $8.76 \pm 0.59 \mathrm{a}$ & $46.90 \pm 1.31 \mathrm{a}$ & $42.20 \pm 0.95 \mathrm{a}$ & $74.33 \pm 3.61 \mathrm{c}$ \\
Background values $^{\mathrm{b}}$ & -- & -- & -- & $20.4 \pm 10.05 \mathrm{~d}$ & $60.6 \pm 18.88 \mathrm{~d}$ \\
\hline
\end{tabular}

Mean values followed by the same letter are not significantly different according to ANOVA and multiple comparisons with Tukey test ( $\mathrm{p}<0.05$ ); b the background values of soils (Luo, 1994).

Total amount of $\mathrm{Cu}$ and $\mathrm{Zn}$ in soils ranged from 35.17 to $46.37 \mathrm{mg} \cdot \mathrm{kg}^{-1}$ and from 74.33 to 130.67 $\mathrm{mg} \cdot \mathrm{kg}^{-1}$, respectively, and both were highest in the site 3. However, in the present study, soil concentrations of $\mathrm{Cu}$ and $\mathrm{Zn}$ are generally lower than those reported in other $\mathrm{Cu} / \mathrm{Zn}$ contaminated sites (Li et al., 2008), although they are significantly higher than their soil background values.

\section{Chemical speciations of $\mathrm{Cu}$ and $\mathrm{Zn}$ in soils}

Soil $\mathrm{Cu}$ and $\mathrm{Zn}$ were present in various forms from easily leachable to recalcitrant ones due to interactions with various soil components. Consequently, the total concentrations cannot provide a precise index representing the influence of $\mathrm{Cu}$ and $\mathrm{Zn}$ on soil microorganisms and enzyme activities (Kunito et al., 2001; Sun et al., 2006). Distribution of $\mathrm{Cu}$ and $\mathrm{Zn}$ forms in the investigated soils is given in Fig. 1. 


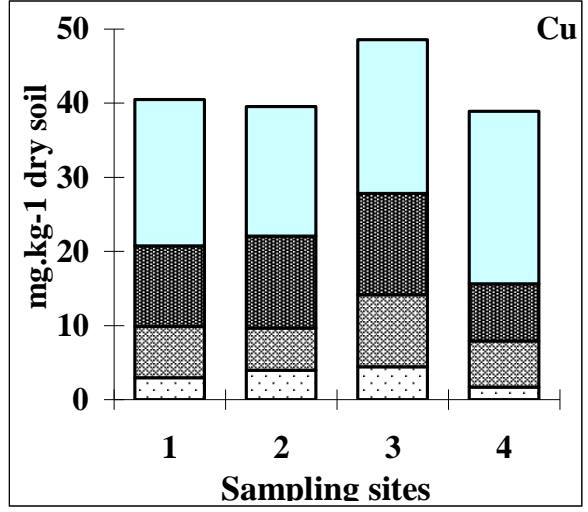

acid soluble reciduble

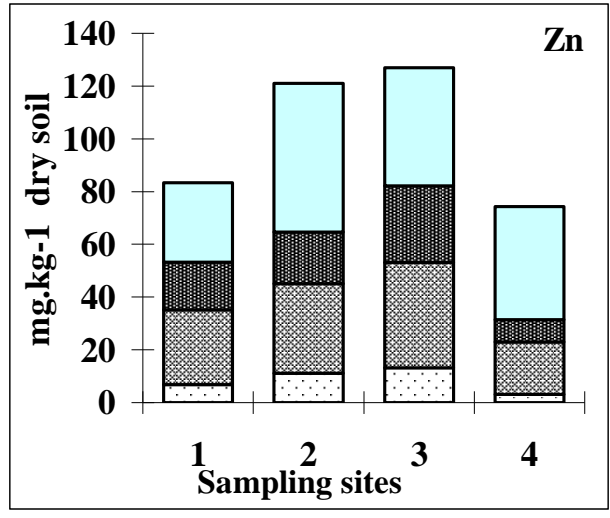

oxidizable $\square$ residual

Fig. 1. Form patterns of $\mathrm{Cu}$ and $\mathrm{Zn}$ in the studied soils

It was shown that $\mathrm{Cu}$ and $\mathrm{Zn}$ were mainly present residual fractions in the investigated soils, and their concentrations in the most labile fraction (acid soluble fraction) were the lowest. In addition, the oxidizable $\mathrm{Cu}$ fraction and the reducible $\mathrm{Zn}$ fraction possessed the highest level among their three bioavailable fractions (acid soluble, reducible- and oxidizable fraction), respectively. These are consistent with those of other reports (Bhattacharyya et al., 2008, Kunito et al., 2001; Saeki and Okazaki, 1993; Saeki et al., 1993). The high percentages of reducible- $\mathrm{Zn}$ and oxidizable-Cu might indicate that the labile fractions of soil $\mathrm{Cu}$ or $\mathrm{Zn}$ would potentially increase in the future by reductive dissolution of $\mathrm{Fe}$ (III)/ Mn (IV) oxides and mineralization of organic moieties under an appropriate condition in the investigated area (Lagomarsino et al., 2011). Finally, in all the investigated sites, the sum of three bioavailable fractions of $\mathrm{Cu} / \mathrm{Zn}$, was highest in the site 3 and the lowest in the site 4 . These trends are consistent with that of their total amount (Table 1). Some studies also reveal that total metal encompasses all metal forms including water soluble and exchangeable ones in soils (Bhattacharyya et al., 2008).

\section{Soil microbial activities}

Soil enzymes and microbial biomass carbon are used to estimate the adverse effects of various pollutants on soil quality (Dick, 1997). Some significant variations in soil mcirobial activities between the soils were indicated in this study (Table 2).

Table 2. Microbial biomass carbon and enzyme activities in each soil

\begin{tabular}{|c|c|c|c|c|}
\hline Parameter & 1 & 2 & 3 & 4 \\
\hline $\begin{array}{l}\text { MBC } \\
\left(\mathrm{mg} \cdot \mathrm{kg}^{-1}\right)\end{array}$ & $17.32 \pm 0.75 a^{*}$ & $16.82 \pm 0.26 \mathrm{a}$ & $14.85 \pm 0.33 \mathrm{c}$ & $19.18 \pm 0.39 d$ \\
\hline $\begin{array}{l}\text { Urease } \\
(\text { mmol NH4kg-1.5h-1) }\end{array}$ & $1.84 \pm 0.04 a$ & $1.94 \pm 0.08 \mathrm{~b}$ & $1.05 \pm 0.08 \mathrm{c}$ & $1.99 \pm 0.02 b$ \\
\hline $\begin{array}{l}\text { Dehydrogenase } \\
\left(\mathrm{mmol} \mathrm{INTF} \mathrm{kg}^{1} \cdot 2 \mathrm{~h}^{-1}\right)\end{array}$ & $7.83 \pm 0.21 a$ & $7.41 \pm 0.20 a$ & $7.05 \pm 0.14 b$ & $7.86 \pm 0.15 a$ \\
\hline $\begin{array}{l}\text { Arylsulfatase } \\
\left(\mathrm{mmol} \mathrm{p} \text {-nitrophenol kg }{ }^{1} \cdot \mathrm{h}^{-1}\right)\end{array}$ & 43.21 $+1.60 \mathrm{a}$ & $37.35 \pm 1.21 b$ & $36.03 \pm 0.90 \mathrm{~b}$ & $41.71 \pm 0.92 a$ \\
\hline
\end{tabular}

*Mean values followed by the same letter are not significantly different according to ANOVA and multiple comparisons with Tukey test $(p<0.05)$

The MBC in the tested soils ranged from 104.85 to $119.18 \mathrm{mg} \cdot \mathrm{kg}^{-1}$, being lowest in the site 3 (Table 2). The tested soils enzymes also showed the significantly lower activities in soils from the site 3 than that from other sites. This indicated the inhibitory effect of metals in the contaminated soils on the production of the enzymes, which were conformed by the Pearson-correlation MBC were all almost significantly and positively correlated with soil $\mathrm{pH}$ and $\mathrm{OM}$ at 0.05 or 0.01 level of statistical significance (Table 3). Therefore, beside of $\mathrm{Cu}$ and $\mathrm{Zn}$, soil organic matter and $\mathrm{pH}$ are also key factors for microbial growth and enzyme synthesis in the investigated soils (Karaca et al., 2010). activities of the studied soil enzymes and soil 
Table 3. Pearson-correlation analysis results between studied parameters

\begin{tabular}{lllll}
\hline & Urease & Dehydrogenase & Arylsulphatase & MBC \\
\hline A1 & $-.919^{* *}$ & $-.873^{* *}$ & $-.741^{* *}$ & $-.959^{* *}$ \\
B1 & -.365 & $-.628^{*}$ & $-.664^{*}$ & -.445 \\
$\mathrm{C} 1$ & $-.903^{* *}$ & $-.890^{* *}$ & $-.776^{* *}$ & $-.968^{* *}$ \\
$\mathrm{Cu}$ & $-.647^{*}$ & $-.838^{* *}$ & $-.806^{* *}$ & $-.735^{* *}$ \\
$\mathrm{~A} 2$ & $-.808^{* *}$ & $-.739^{* *}$ & $-.652^{*}$ & $-.904^{* *}$ \\
$\mathrm{~B} 2$ & $-.676^{*}$ & $-.659^{*}$ & $-.594^{*}$ & $-.870^{* *}$ \\
$\mathrm{C} 2$ & -.410 & -.404 & -.374 & -.132 \\
$\mathrm{Zn}$ & -.455 & $-.674^{*}$ & $-.657^{*}$ & $-.606^{*}$ \\
$\mathrm{pH}$ & $0.839^{* *}$ & $0.820^{* *}$ & $0.809^{* *}$ & $0.670^{*}$ \\
$\mathrm{OM}$ & $0.760^{* *}$ & $0.889^{* *}$ & $0.807^{* *}$ & $0.880^{* *}$ \\
\hline
\end{tabular}

*,** Correlation is significant at 0.05 and 0.01 levels, respectively; the same below

Influence of metals on soil microbial parameters

In the present study, partial correlations analysis, under the control of $\mathrm{pH}$ and $\mathrm{OM}$, were conducted to distinguish the effects of trace metals on the microbial parameters from the soil properties. The total metal amount and its bioavailable values (acid soluble-, reducible- and oxidizablefractions) were used for the analysis. The results obtained were showed in Table 4.

Table 4. Partial correlations of metals forms and microbial properties under the control variables of $\mathrm{pH}$ and $\mathrm{OM}$

\begin{tabular}{lllll}
\hline & Urease & Dehydrogenase & Arylsulphatase & MBC \\
\hline A1 & $-.871^{* *}$ & $-.857^{* *}$ & -.341 & $-.926^{* *}$ \\
B1 & .522 & .156 & $-.602^{*}$ & .378 \\
C1 & $-.858^{* *}$ & $-.883^{* *}$ & -.436 & $-.935^{* *}$ \\
Cu & -.257 & -.517 & -.540 & -.552 \\
A2 & $-.815^{* *}$ & $-.844^{* *}$ & -.479 & $-.926^{* *}$ \\
B2 & $-.799^{*}$ & $-.805^{* *}$ & -.547 & $-.946^{* *}$ \\
C2 & .389 & .503 & .470 & $.634^{*}$ \\
Zn & -.436 & $-.714^{*}$ & $-.911^{* *}$ & $-.638^{*}$ \\
\hline
\end{tabular}

As shown in Table 4, the labile $\mathrm{Cu} / \mathrm{Zn}$ forms, such as its acid soluble, reducible and oxidizable fractions, were significantly negatively correlated with the studied enzyme activities at 0.05 or 0.01 probability levels. According to Bhattacharyya et al. (2008), the MBC and soil enzymes activities were significantly and negatively correlated with the metal labile forms as well as with its total metal concentrations due to the colinearity effect because total metal encompasses all the metal forms. However, no significant inhibition of the total $\mathrm{Cu}$ amounts on $\mathrm{MBC}$ and enzyme activities except of Arysulfatase were found in the partial correlation analysis (Table 4), although the adverse effects of the total $\mathrm{Zn}$ amounts on dehydrogenase, arysulfatase and MBC is increased in the partial correlation analysis (Table 4). These results indicate that labile metal forms are the most important factors regulating MBC and enzyme activities in heavy metal contaminated soils (Karaca et al., 2010).

The $\mathrm{Cu}$ and $\mathrm{Zn}$ concentrations in the present study (Table 1) were quietly lower than the lowest observed adverse effect concentrations (LOAECs) of $\mathrm{Cu}\left(150 \mathrm{mg} \cdot \mathrm{kg}^{-1}\right)$ and $\mathrm{Zn}$ at Ludington (McGrath et al., 1995). However, the significant inhibition of their forms on the tested microbial parameters was also found in the investigated soils. This may be related to that there are wide variations in the concentrations because various soil properties may also influence the LOAECs (Baath, 1989; McGrath et al., 1995).

\section{Conclusions}

The trace elements $\mathrm{Cu}$ and $\mathrm{Zn}$ were slightly enriched in the investigated soils according to the soil back ground values, and they were mostly present in the residual fractions in bulk soil. Moreover, the correlation analysis between chemical speciation and soil microbial parameters also revealed that the labile forms of $\mathrm{Cu}$ and Zn could exert an inhibitory effect on soil Urease, Dehydrogenase and soil microbial biomass in the investigated field. The results signify the important role of the labile metal fractions exerting inhibitory effect on the microbial parameters even though they occupy only a small part of the total metal concentration.

\section{Acknowledgements}

The study was supported by the National Natural Science Foundation of China (41001145), and the $\mathrm{Ph} . \mathrm{D}$ Foundation of Shandong University of Technology (406033). 


\section{References}

Baath, E. 1989. Effects of heavy metals in soil on microbial processes and populations (a review). Water Air \& Soil Pollution. 47: 335379.

Bhattacharyya, P., Tripathy, S. and Chakrabarti, K. 2008. Fractionation and bioavailability of metals and their impacts on microbial properties in sewage irrigated soil. Chemophere. 72: 543-550.

Dai, W.H., Huang, Y. and Wu, L. 2009. Relationships between soil organic matter content (SOM ) and pH in top soil of zonal soils in china. Acta pedologica snica. 146 (5): 851-860.

Dick, R.P. 1997. Soil enzyme activities as integrative indicators of soil health. In: Pankhurst C E, Doube B M, Gupta V V S R. (Eds.), Biological Indicators of Soil Health. CAB International, New York. pp. 121- 156.

García, C., Hernandez, T. and Costa, F. 1993. The dehydrogenase activity of soils as an ecological marker in processes of perturbed system regeneration. In: Gallardo J F. (Ed.), Proceedings of the Eleventh International Symposium of Environmental Biogeochemistry, Salamanca, Spain. pp. 89100.

Ge, Y., Murray, P. and Hendershot, W.H. 2000. Trace metal speciation and bioavailability in urban soils. Environ. Pollution. 107: 137-144.

Giller, K.E., Witter, E. and McGrath, S.P. 2009. Heavy metals and soil microbes. Soil Biol. Biochem. 41 (10): 2031-2037.

Gregorich, E.G., Wen, G. and Voroney, R.P. 1990. Calibration of rapid direct chloroform extraction method for measuring soil microbial biomass C. Soil Biol. Biochem. 22: 1009- 1011.

Hinojosa, M.B, Carreira, J.A. and Garcia-Ruiz, R. 2004. Soil moisture pre-treatment effects on enzyme activities as indicators of heavy metal-contamiated and reclaimed soils. Soil Biol. Biochem. 36: 1559- 1568

Joergensen, R.G. 1995. Microbial biomass. In: Alef, K, Nannipieri P (Eds), Methods in applied soil microbiology and biochemistry. Academic Press, London. pp. 382-386.

Karaca, A., Cetin, S.C. and Turgay, O.C. 2010. Effects of heavy metals on soil enzyme activities. I. Sherameti and A. Varma (eds.): Soil Heavy Metals, Soil Biol. 19: 237-262. DOI 10.1007/978364202436811.

Khan, S., Cao, Q. and Hesham, A.E.L. 2007. Soil enzymatic activities and microbial community structure with different application rates of $\mathrm{Cd}$ and $\mathrm{Pb}$. J. Environ. Sci. 19: 834-840.

Kunito, T., Saeki, K. and Goto, S. 2001. Copper and zinc fractions affecting microorganisms in long-term sludge-amended soils. Bioresourse \& Tech. 79: 135- 146.

Lagomarsino, A., Mench, M., Marabottini, R., Pignataro, A., Grego, S., Renella, G. and Stazi, S.R. 2011. Copper distribution and hydrolase activities in a contaminated soil amended with dolomitic limestone and compost. Ecotoxicology and Environmental Safety. 74 (7): 2013-2019.

Li, L.F., Zeng, X.B. and Bai, L.Y. 2008. Accumulation of copper and zinc in soils under different agricultural and natural field (Chinese). Acta Ecologica Sinica. 29 (9): 4372-4380 .

Li, X., Poon, C.S. and Liu, P.S. 2001. Heavy metal contamination of urban soils and street dusts in Hong Kong. Applied Geochemistry. 16: 1361-1368.

$\mathrm{Lu}$, R.K. 1999. Chemical analysis of agricultural soil. Beijing: Agricultural Science and Technology Press of China.

Luo, M.J. 1994. Shandong Soil. Beijing: Agriculture Press of China.

MoGrath, S.P., Chaudri, A.M. and Giller, K.E. 1995. Long-term effects of metals in sewage sludge on soils, microorganism and plants. J. Indus. Microbiol. Biotech. 14: 94- 104.

Meng, Q.H., He, M.R. and Wang, Q.Z 1996. Research on the soil condition and its nutrient limitation factor in high yield farmland of the main soil types of Shandong Province. J. Soil Sci. 27 (6): 256-258.

Quevauviller, P., Rauret, G. and López-Sánchez, J.F. 1997. Certification of trace metal extractable contents in a sediment reference material (CRM 601) following a three-step sequential extraction procedure. Science of Total Environment. 205: 223-234.

Saeki, K. and Okazaki, M. 1993. Heavy metal accumulations in a semenclosed hypereutrophic system: lake Teganuma, Japan. Part 2. Heavy metal accumulations in sediments. Water air \& soil pollution. 69: 79-91.

Saeki, K., Okazaki, M. and Matsumoto, S. 1993. The chemical phase changes in heavy metals with drying and oxidation of the lake sediments. Water Research. 27: 1243-1251.

Sun, S.J., Xu, J., Dai, S.G. and Han, X. 2006. Influences of copper speciation on toxicity to microorganisms in soils. Biomedical Environ. Sci. 19: 409-413.

Tabatabai, M.A. and Bremner, J.M. 1970. Arylsulphatase activity of soils. Soil Science Society of America Proceedings. 34: 225229.

Tabatabai, M.A. and Bremner, J.M. 1972. Assay of urease activity in soils. Soil Biol. Biochem. 4: 479-487. 
Trevors, J.T. 1984. Dehydrogenase activity in soil: a comparison between the INT and the TTC assay. Soil Biol. Biochem. 16: 673-674.

Wang, Y., Shi, J., Lin, Q., Chen, X. and Chen, Y. 2007a. Heavy metal availability and impact on activity of soil microorganisms along a $\mathrm{Cu} / \mathrm{Zn}$ contamination gradient. J. Environ. Sci. 19: 848-853.
Wang, Y., Shi, J., Lin, Q., Chen, X. and Chen, Y. $2007 \mathrm{~b}$. The influence of soil heavy metals pollution on soil microbial biomass, enzyme activity, and community composition near a copper smelter. Ecotoxicology and Environmental Safety. 67: 75-81. 